\title{
III アミ酸輸液を中心として
}

\author{
新渇大学医学部第一外科教室（指 導武堺哲 郎 教 授)
}

外科領城，特に手術後に於て生体には手術といら 一つの Stress によつて体蛋白の異化六進がおこり ，電解質代謝の異常が現れて参ります。この様な変 動はスライドのようにその因子の一つとして副腎皮 犋ホルモンの増量からも推察されるのであります。 （図 1 ）一方街後の Catabolism の六淮怯避淂な
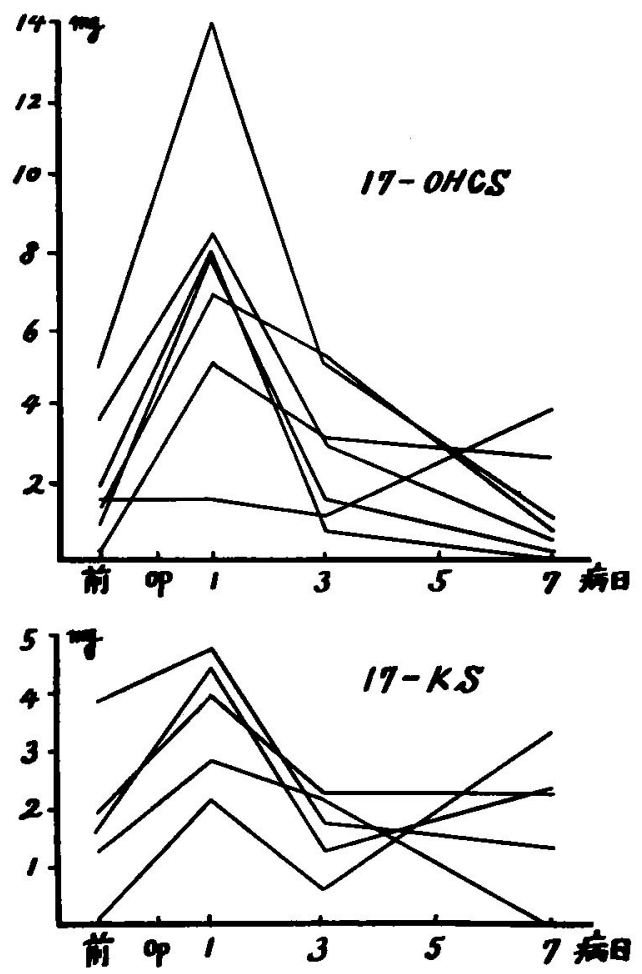

图 1 術後副霄皮䨘ホルモンの变動(尿)

いものでありましようが，出来るだけこれを最少限 にくい止めたいというのが私共の念願でなければな りません。その一つの方法としてアミノ酸輸液の効 果と，更にこれと関連して糖所及びカリウム代謝に ついて検尉を加えてみます。

\section{1. 経静脉輸度}

先ゔ非経腸的投与法の中，最も愛用されます経静 脉輸液について申し上げます。使用致しましたアミ ノ酸は主としてFAOの整定基集にもとつきき作製さ
れました 10\% ES-Polytamin であります。

アミノ酸投与例と，これを投与しない例とを比較 しますと，投与例では術後の窒素平衡は $55.6 \mathrm{~g}$ 空素 量が負でありますのに比べ，投与しない例では72.9 g の負となって遭玑多くなります。又空素平衡を みますと投与例で第 7 病日にようやく正に回復しま すが，非投与例では第13病日によ5やく正に回復致 します。明らかにアミノ酸投与による効果を窥らこ とが出来るのであります。（図 $2,3 ）$

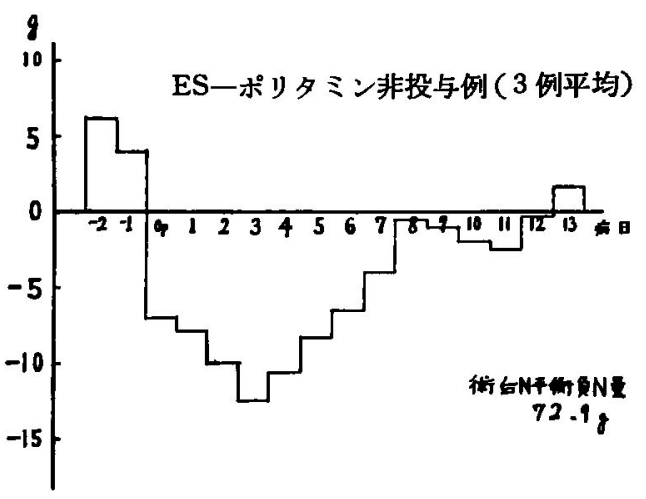

図 2 觧注空素平衡

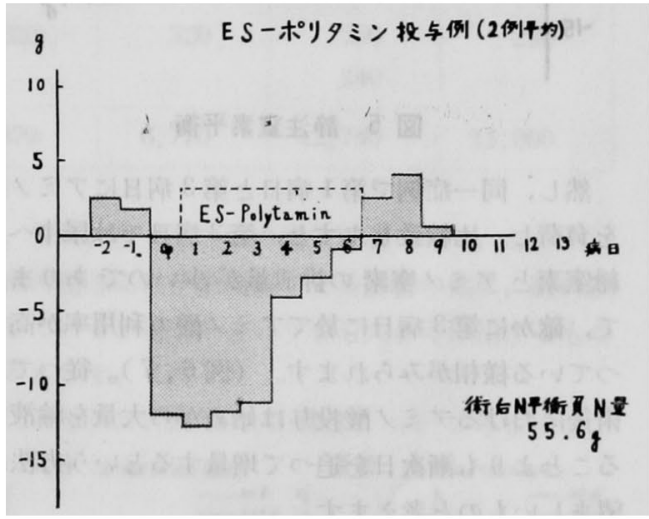

図 3 静注空素平得

このことを同じ投与例同志で比較しますと，毎日 $500 \mathrm{cc}$ 投与の症例では，毎日 $200 \mathrm{cc}$ 投与の症例に比 べ，尿中に排泄される総空素及びアミノ窒素は增量 阔しますが，空素平衡とい5点からみれば，覃ろ負 
の傾向が少いのでありまして, $500 \mathrm{cc}$ 投与致しまし ても、これは全く無効であるとは断じ得忠せん。 (図 4,5 )

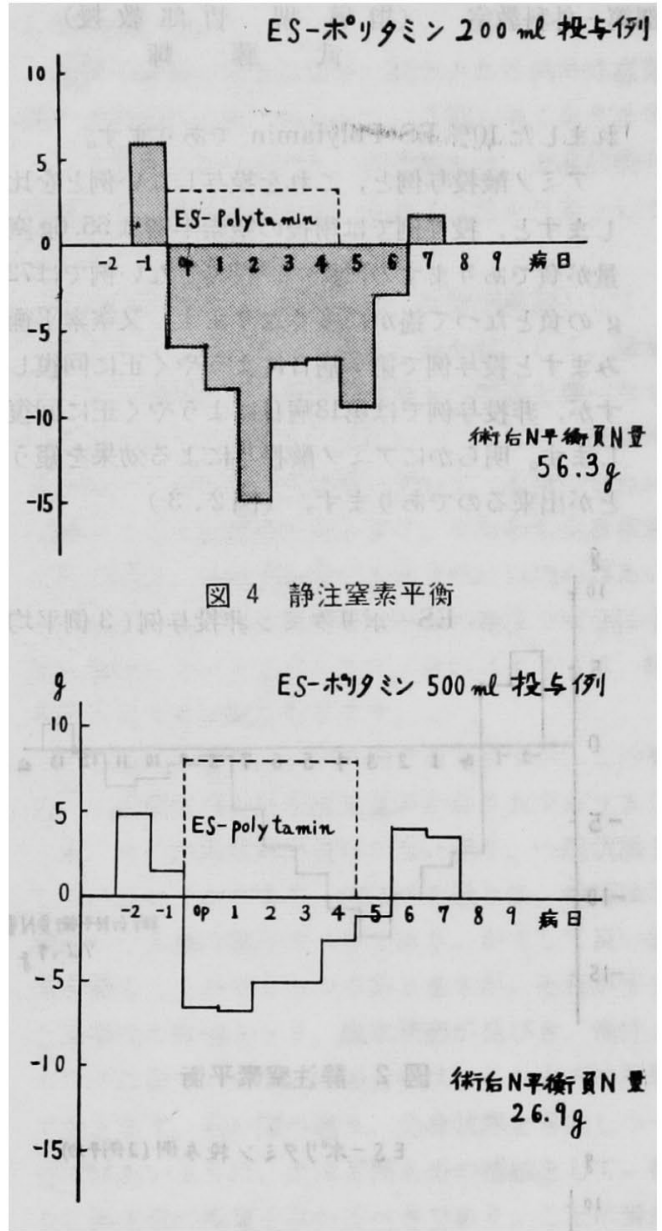

図 5 静注窒素平衡

然し，同一症例で第 1 病日と第 3 病日にアミノ酸 を負荷し，比較致しますと，第 3 病日では尿中への 総窒素とアミノ空素の排泄量が少いのでありまし て，確かに第 3 病日に於てアミノ酸の利用率が高ま つている样相がみられます。（図 6，7）。従つて， 術後におけるアミノ酸投与は始めから大量を輸液す ることよりも漸次日を追つて增量するといら方法が 望ましいものと考えます。

尚, 輸液する場合の注入速度ですが, $10 \%$ アミノ 酸溶液 $200 \mathrm{cc}$ と $5 \%$ \%゙ドウ榶液 $500 \mathrm{cc}$ を混せた場合 には 1 分間 60 滴以内, $10 \%$ アミノ酸溶液 $300 \mathrm{cc}$ と 5 $\%$ \%ブドウ糖液 500cc を混ぜた場合には45滴以内の速 度で注入すれば利用率も良く，患者に与える肉体的

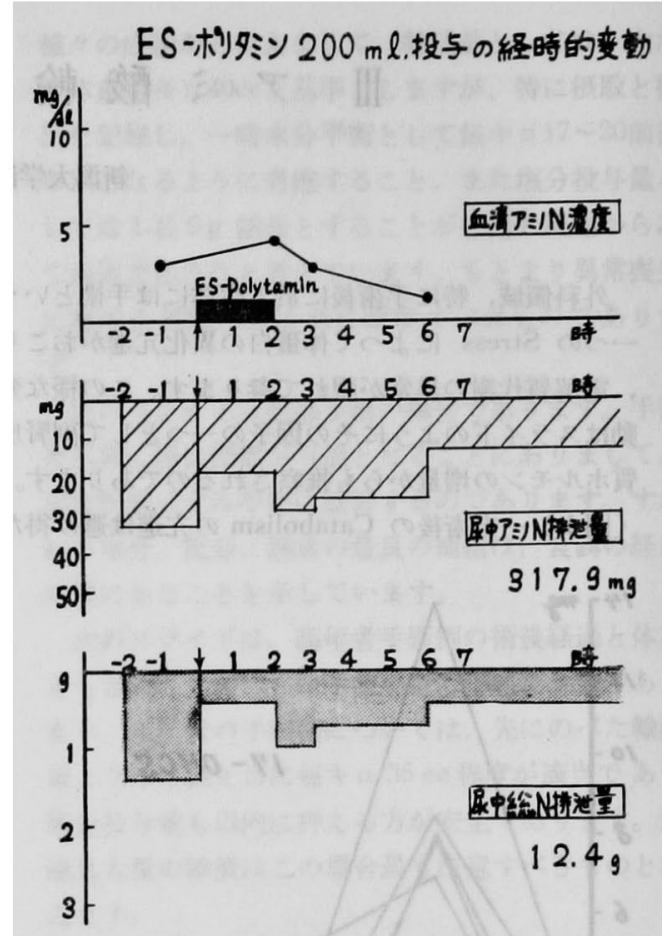

図 6 静注(第1 病日)

\section{$E S$ ーポリタミン $200 \mathrm{ml}$ 投与の絓時的变勏}
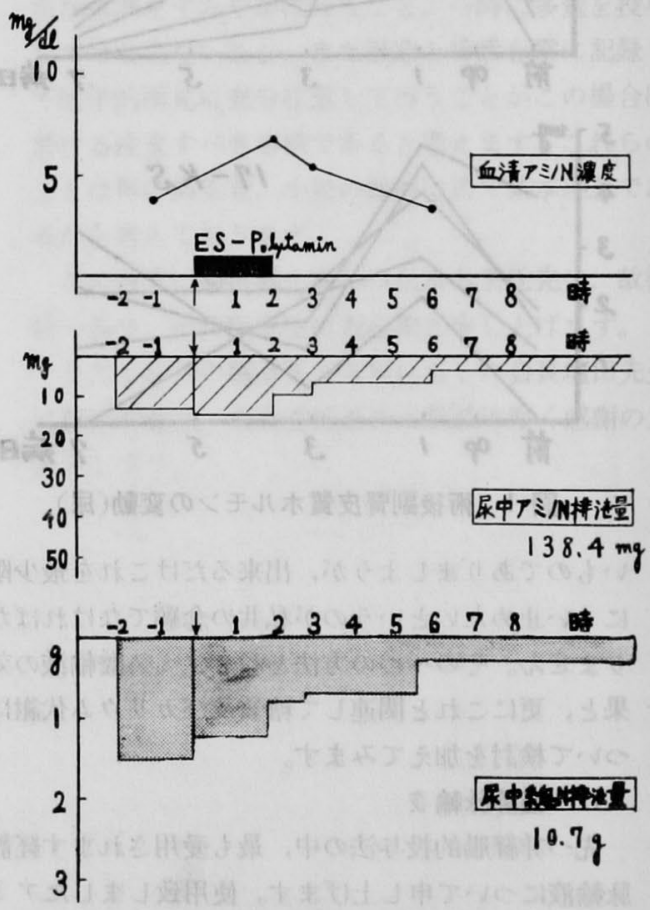

図 7 静注（第3 病日） 
負担も比単的少くてすみます。メアミノ酸量の投与 総カロリーに対ナる比率につきましては，数多くの 報告がありますが，私共の検索の結果では，既に堺 教授が報告致しております梯に，20 30\%が最も良 、利用率を得る様に思います。（表 1 ）勿論この值 も患者の状態によって異り, anabolicの過程が六進 している場合には 30 40\%の割合に投与致しまして も利用されらる様に思います。高山教授は a nabolic steroid を併用して 45 50\%の投与でも好結果をう ることを報告しておられるのでありまして，総力口 リーに対するアミノ酸比につきましては尚検款の余 地がありましよう。

\section{表 1 䱢脉内注入至適速度}

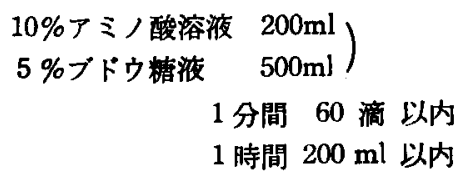

静注投与の際の栄荃素カロリー比

$Y$ ミ , 酸 : $20 \sim 30 \sim 40 \%$

精翼・脂啠： $80 \sim 70 \sim 60 \%$

表 2 各理結晶アミノ酸混合溶液租成

\begin{tabular}{|c|c|c|c|c|c|c|c|}
\hline 略 称 & 分画 & モリアミンั & $\begin{array}{l}\mathbf{E} \\
\text { ポリタミン }\end{array}$ & No.1 液 & No. 2 液 & No. 3 液 & No. 4 液 \\
\hline \multirow{3}{*}{$B_{1-3}$} & L-Lys. & 2,230 & 1,440 & 1,440 . & 720 & 1,440 & $1, \dot{4} 40$ \\
\hline & L-His. & 400 & 500 & 500 & 250 & 500 & 500 \\
\hline & L-Arg. & 800 & 1,000 & 1,000 & 500 & 1,000 & 1,000 \\
\hline $\mathrm{N}_{1}$ & Gly & 1,000 & 1,370 & 1,370 & 2,740 T & 4,110 & 4,110 \\
\hline \multirow{3}{*}{$\mathrm{N}_{3}$} & L-Leu. & 1,230 & 1,090 & ‥-- & {[} & 1,090 & 1,000 \\
\hline & L-Ileu. & 550 & 960 & $-\ldots$ & $4:$ & 960 & 500 \\
\hline & L-Val. & 610 & 960 & -...- & - & 960 & 600 \\
\hline \multirow{7}{*}{$N_{4+5}$} & L-Met. & 50 & 960 & 960 & 960 & 960 & 500 \\
\hline & L-Phe. & 870 & 640 & 640 & 640 & 640 & 640 \\
\hline & L-Thr. & 330 & 640 & 640 & 640 & 640 & 430 \\
\hline & DL-Thr. & 420 & $\div$ & $---\cdots$ & - & $-\cdots$ & - \\
\hline & L-Try. & -- & 200 & 320 & $320 ?$ & 200 & 290 \\
\hline & DL-Try. & $\begin{array}{r}180 \\
\end{array}$ & 240 & $\cdots-$ & & 240 & -..- - \\
\hline & 合 計 & 8,670 & 10,000 & 6,870 & 6,770 & 12,740 & 11,000 \\
\hline
\end{tabular}

投与するアミノ酸の配合比に関しましては F A O の整定基準が一応合理的なものと見做されている現 状でありますが，私共は市販のアミノ酸溶液の他に 装の No: 1 から No. 4 までの液を作製し，一方教室 の赫井, 若佐等により䣨床応用の可能となりました 高電圧澽紙泳動法に 基きこれを検討してみまし た。（表 2 )

術後は疾患の如何を問わず，血清遊離?ミノ酸 分画の変動为みられますが，特に $\mathrm{N}_{3}$ 分画，虾ち Leucine, Isoleucine, Valine が著明に增加致しま 寸。

然し第 1 病日より経口摄取を行つた乳癌例と第 3 病日より経口接取を行つた胃癌例とを比較します
と, 胃癌例に $\mathrm{N}_{3}$ 分画の增加が著るしく, この $\mathrm{N}_{3}$ 分画の增加には手術侵撉による影零の他に, 経口提 取しているかどうかといら事も大きく作用するるの と考えます。（図 8)

これをアミノ酸投与の場合についてみますと，
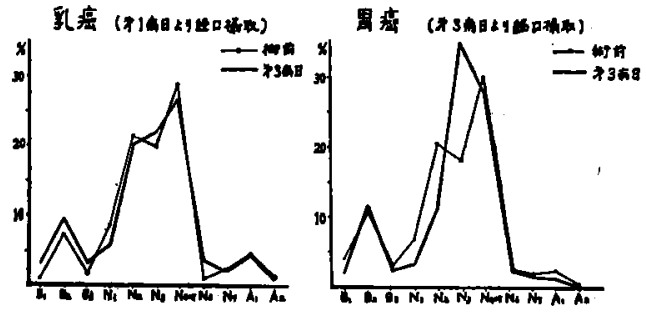

图 8 衍前及ひ第3病日血清遊離アミノ酸分画 
ES-Polytamin 投与例ではアミノ酸利用率之窒素 平衡の点で最も良い結果を示すにも拘らず， $\mathrm{N}_{3}$ 分 画の增加は著明であります。一方, 試作致しました No.4液, これは ES-Polytamin と Moriamin-S の中間のものと御理解戴いているのでありますが, これを投与しますと，血清遊離厂ミノ酸分画の变動 が少く, 特に $\mathrm{N}_{3}$ 分画は殆んど上昇しません。梊的 には生体に良く適合したものと思われるのですが， ES-Polytamin に比べアミノ酸利用率や空素平衡の 点でやや劣つております（表 3 , 図 9)。

表 3 術後の尿中恖アミノ-N (mg/日)

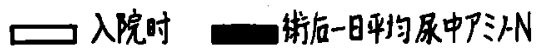

無观理群

No.1浓投与群

$100 \quad 300$

$5 \sin ^{m}$

t1:

No.2波投蛲

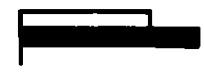

No.3派投与群

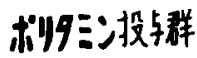

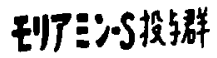

No.4波被暲

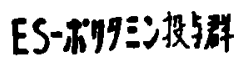

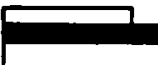

$+36.3 \%$

$+245 \%$

$+144^{4}$

$+7.0^{6}$

$-11.1 \%$

$-142^{\prime}$

$-5 a 8^{3}$

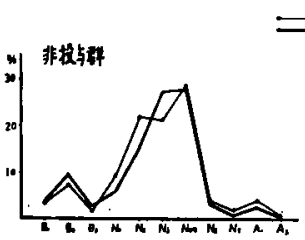

二
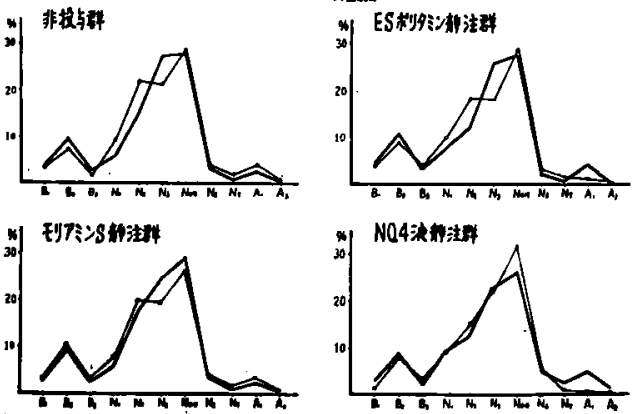

図 9 術前及ひ第3病日血清游離アミノ酸分画

この様にアミ゙酸溶液の犋と量の問題，即ちアミ ノ酸の配合比にうきましては, 尚一層の検索が必要 と思えます。

次にカロリ一源として最も重要なブドウ糖につい て申し上げますと，ブドウ楉の注入速度は諸家によ
り必ずしも同一ではありませんが，私共の検索の結 果では術前術後を問わず， 1 時間，体重 $1 \mathrm{~kg}$ 当り $0.4 \sim 0.5 \mathrm{~g}$ 以内の速さで注入すれば尿糖む出現せず ，良く利用されます（表4）。

表 4 ブドウ裙注入速度と尿裙出現

\begin{tabular}{|c|c|c|c|c|c|c|}
\hline \multirow{2}{*}{ 症例 } & \multirow{2}{*}{$\underset{\mathrm{Kg}}{\mathrm{Kg}}$} & \multirow{2}{*}{ 病名 } & \multirow{2}{*}{ 手術々式 } & \multicolumn{3}{|c|}{ 注入速度 $\mathrm{g} / \mathrm{kg} / \mathrm{hr}$} \\
\hline & & & & 街前 & *1 勏日 & \#3紊且 \\
\hline 1 & 45.5 & |胆石症 & 月目のう剔出 & 0.17 & 0.23 & 0.55 \\
\hline 2 & 65 & 目璄来 & 周大㘮除 & 0.23 & & 0.50 \\
\hline 3 & 53 & 胆石症 & 姐的剔出 & 0.57 & 0.47 & 0.47 \\
\hline 4 & 57 & 累峦 & 用要全㔀 & 0.35 & & 0.44 \\
\hline
\end{tabular}

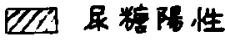

一方，糖代謝についてみますと，血糖值は胃切除 例では第 2 病日に術前值に復しますが, 肺切除例で は, 第 $3 \sim$ 第 5 病日で渐く術前値に復しておりま す。（図10）血中の乳酸と焦性ブドウ酸とは胃切除 例では第 2 病日に術前值に復㷌しますし, 肺切除例 では第 3 病日に復帰しているのでありまして, 開胸 手術，特に肺切除の場合に於ては十分な酸素吸入と 同時にビタミン $\mathrm{B}_{1}$ の如き糖代謝を促進する物質を 大量に投与することが必要でありましよう。（図11 12)
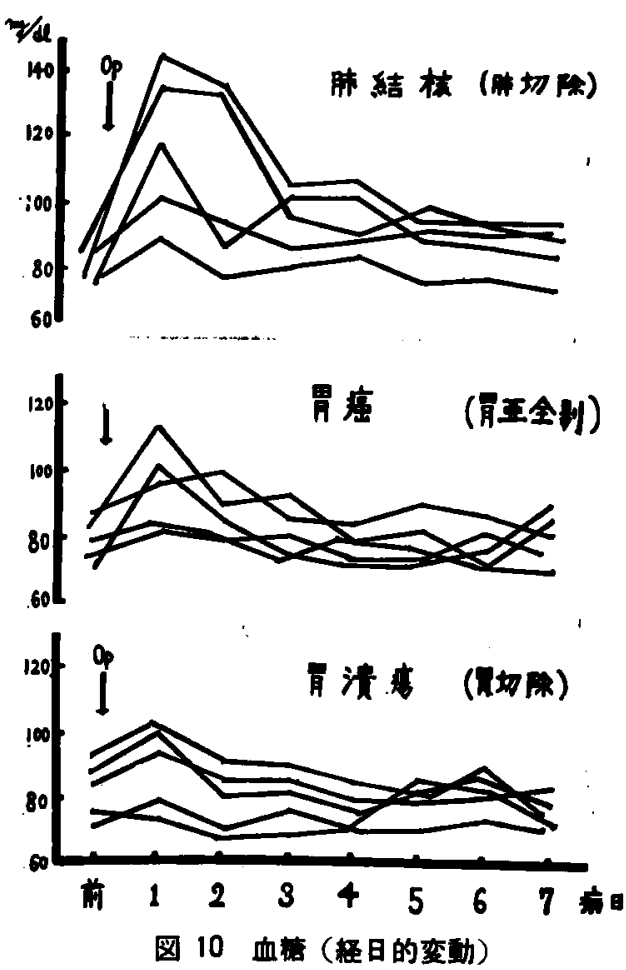

图 10 血裙（轻日的变彭） 

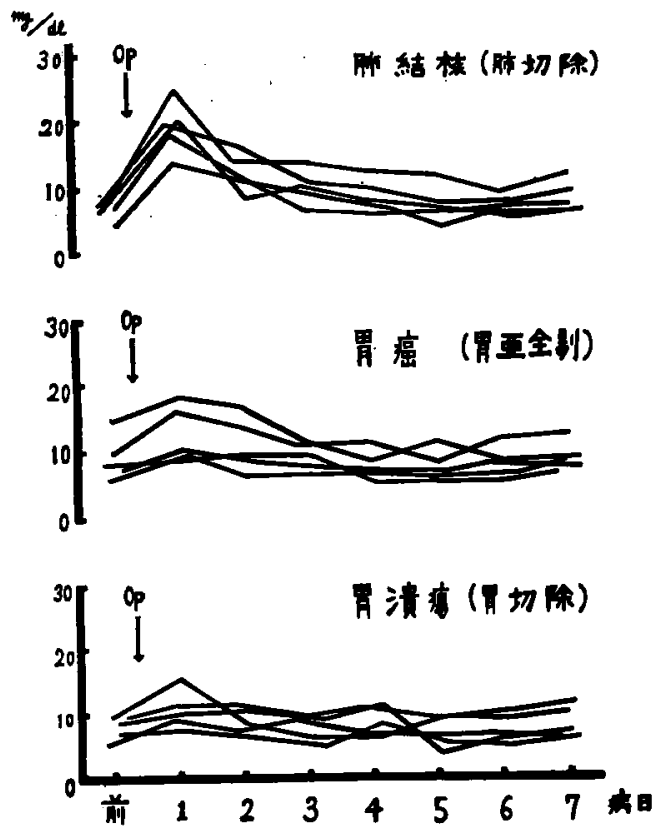

图 11 乳酸 (経日的変蛙)
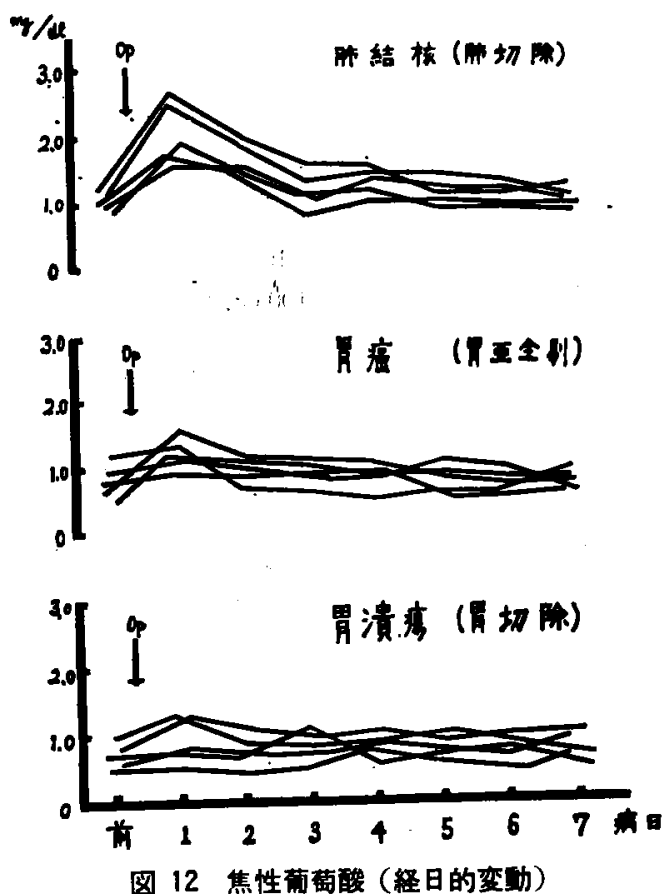

次に水分, 笔解筫の補給であります。水分補給は 術後, 毎日, 体重 $1 \mathrm{~kg}$ 当り $40 \mathrm{cc}$ 前後を基準とし, 体温 1 度上昇ごとに $10 \%$ 増量し，胃吸引液を計算に 入れ輸液を行ってみましたが, 術後第 5 病日頃には
自発的な程口掞取のみに任せたためか, 循環血浆量 は減少し, 第 7 病日に始めて術前値近くまで回復す る样相がみられます。（図13）

窒素 $1 \mathrm{~g}$ 排泄に平行してカリウムが $2.75 \mathrm{mEq}$ 以 上排泄されるという事実がありますから，1 日の食
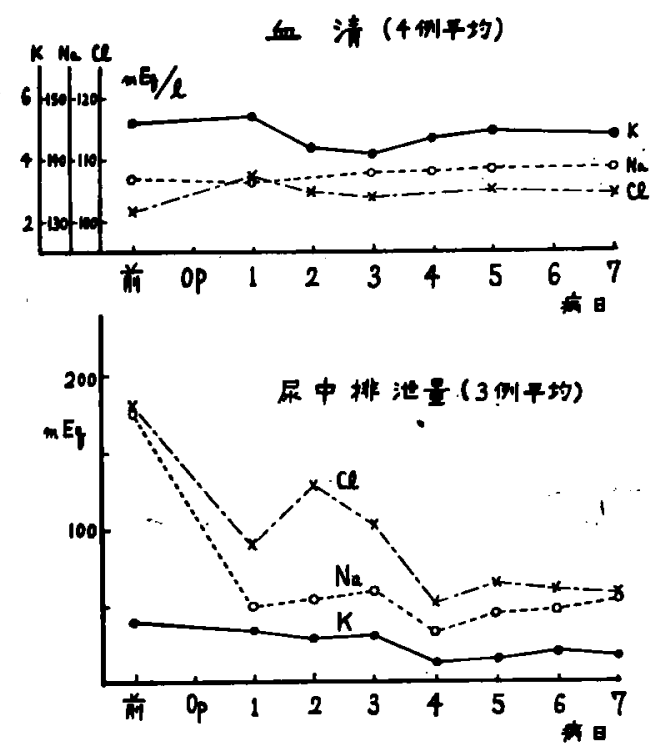

图 13 手術後の循懪血龊变勒

塩投与は 40〜 70 mEq にとどめ, 塩化カリウムは手 術翌日より 4 日間, 毎日, $15 \sim 20 \mathrm{mEq}$ を投与致し てみました。血清カリウム㴃度をみますと，カリウ 厶投与例では術後僅かな変動を示すに過ぎません が，カリウムを投与しない例では，第 2 ，第 3 病日 に最も減少し，第 7 病日に至つても術前より低い值 を示しています。術中カリウム排泄量は両者とも第 4 , 第 5 病日に最も減少しますが, 第 7 病日にはカ リウム投与例では術前值の70\%に達します。これに 比べ非投与例では術前值のに達するに過ぎません。 ナトリウムとクロールは血清, 尿とも両群に著るし い差異がごさいいせん。（図14，15）ただし，この 様な結果からみますと, 私共の投与量はやや少なか つた様に思いますが，術後におきましてはアミノ酸 投与を行 尿開始と共に投与し，経口汬取が可能となつてから 数日後まで投与を続行しますればカリウム平衡は略 正常に保たれらるのではないかと考えます。勿論こ の際，心疾患の有る，無しによつて投与量を加诚す る事は言らまでもありません。

従来私共は術後に見られる腹水や浮腫に対し利将 
(131I-Albumin K小3测定值１5例）

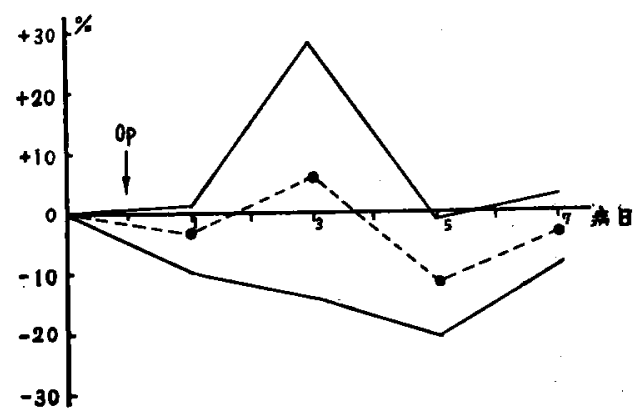

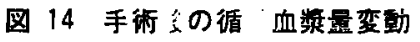

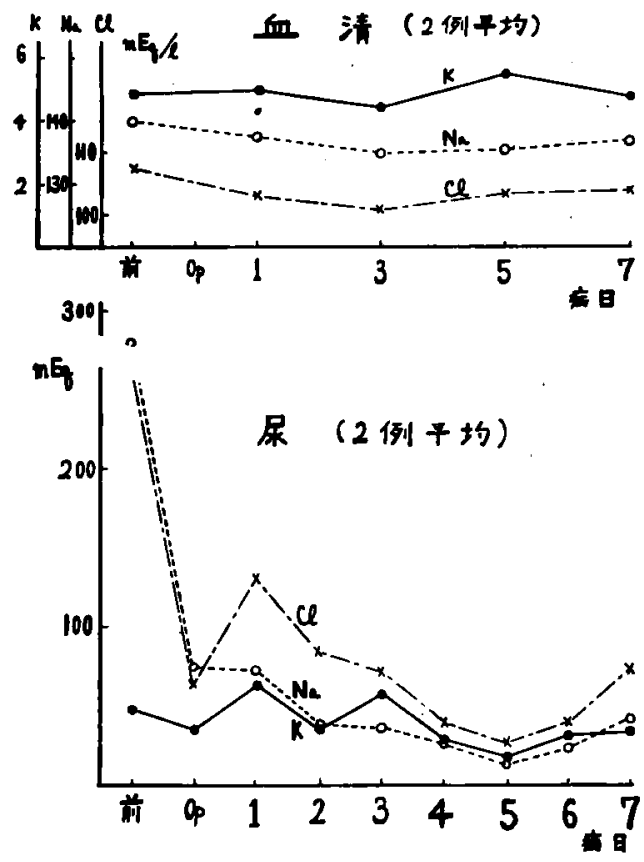

图 15 術後電解鲳の变動（K投与例）

郕を使用し，カリウムの排泄量が多いことに苦慮致 しておりましたが，最近この様な場合に抗 Aldosterone性利尿剂であります“Aldactone”を使用し てみました。症例は胆汁性肝便変の患者ですが，毎 日 $300 \mathrm{mg}$ を投与しましたところ，尿量及びナトリ ウム，クロールの示中排泄量は投与後，直ちに6〜 7 倍に達しますが，尿中カリウム非泄量は投与 7 日 目で 4 倍に達するに過ぎません。血清カリウム渡度 は一過性に上昇致しますが，投与 4 日目に既に正常 值に復しておりますから，腹水或は浮腫を消祓せし めつつ組織の修復を計ろらとする場合等には Al一 dactone の投与は有効なものと思いました。(図16)
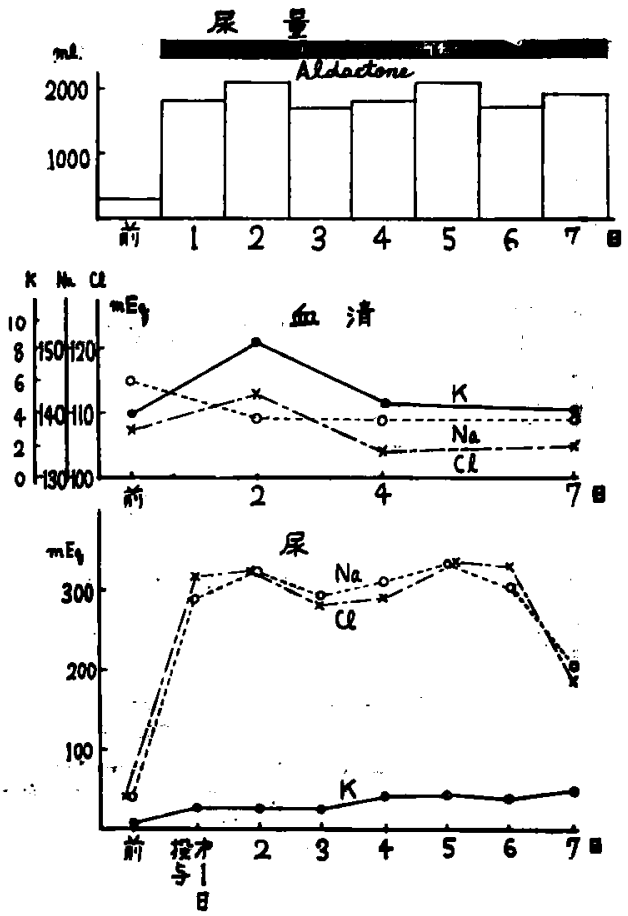

図 16 アルダクトン投与例 $(300 \mathrm{mg} /$ 日)

カリウムの補給には塩化カリウムを通常使用しま すが，私共はカリウム投与の一方法としてアスパラ ギン酸のカリウム，及びマグネシウム塩，略称 Au -610 を使用してみました。使用の際に，この $10 \%$ 溶液 $10 \mathrm{cc}$ を $5 \%$ ブドウ鋉液 $100 \mathrm{cc}$ に混合し，点谪 静注致します。

第 3 病日に $A u-610,40 \mathrm{cc}$ を貧荷します之，血清 ナトリウムやクロール港度はやや低下しますが，力 リウム源度は上界し，尿でもナトリウムやクロール に比べ，カリウムの排出される割合が少いようであ りまして，カリウムが比較的良く保持される様に思 います。”（图17)

胆筞炎で入院し，低カリウム，高クロー几血症を 認めた患者に最初 Solita 液を投与しましたところ， 血清カリウム渡度は一時やや上昇しますが，再び低 下し，血清クロール浱度が益々上昇するため, 生理 的食塩水と Au-610 の投与に替えてみましたとこ ろ，投与後 5 日目には血清カリウム及びクロ一ル涨 度も正常に復し，全身状態も極めて良好となりまし た。私共は 6 例に Au-610を使用しましたが，副作 用住く認められません。これらの経験からみます と低カリウム血症, 特に高クロール血症を伴ら場合 

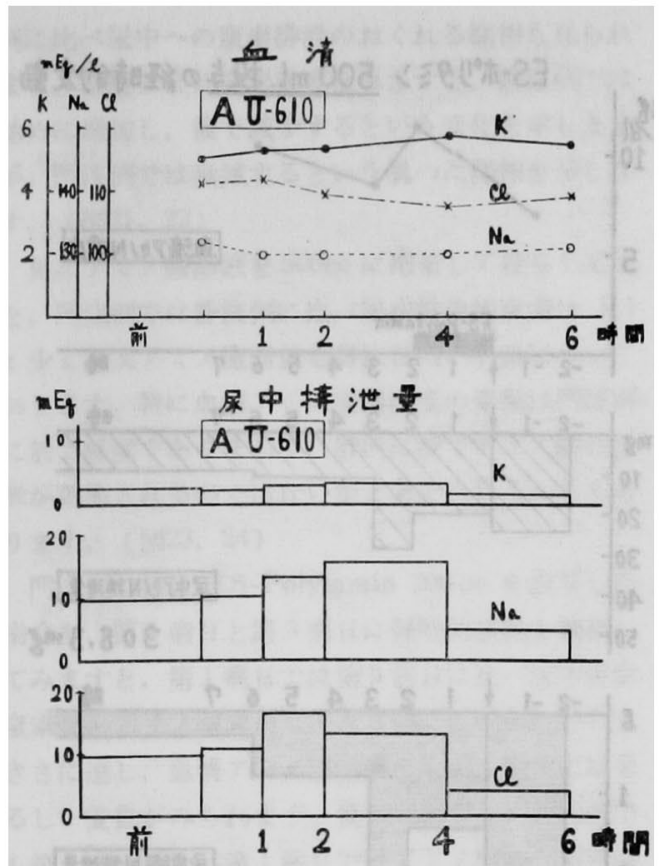

図 17 アスパラギン酸 投与例

(Av-610 $\mathrm{ml}$ 頁荷)

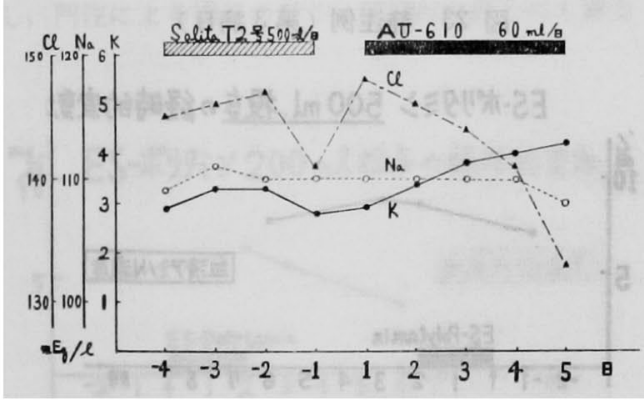

图 18 アスパラギン醨 $\mathrm{K}-\mathrm{Mg}$ 塩投与例

$(A u-610)$ ' $2 *$

には進んで使用すべきものと考えております。（図 18)

\section{2. 経門脉輸夜}

次に経門脉輸液について申し上げます。

既に昭和18年斎藤教授がブドウ糖の門注の効果に

ついて報告されておりますが, 私共は術後の栄羕改 善を目的として, 絬晶アミノ酸溶液の門脉内輸液を 試みてみました。

被検例は食道癌”例, 胃癌 2 例, 胃 -十二指腸沮 瘍 8 例，計12例であります。

カテーテルの 掩入は松本, 有地氏等の方法に準 し, 開腹手術終了時, 腹膜繾合前に横行結腸間膜の
適当な静脉を選び，カテーテルを門脉幹に達するま で㨉入致します。末稍静脉は結禁離断し，カテーテ ルを挿入した静脉は約 $3 \mathrm{~cm}$ ほど中心側へ遊離し， 腸間膜の一部を腹膜に固定致します。カテーテれレは 插入した静脉と共に腹膜区ひ皮下組織に 固定した 後, 外部一誘導致します。衍後の輸液は総てこのカ テーテルを通じて行い,第 4 病日輪族終了後，抜去 致しましたが，本法施行例では出血，感染，血栓形 成, 腸開塞などの合併症は 1 例も認められませんで した。

最初にアミノ酸輸液の効果についてみますと；窒

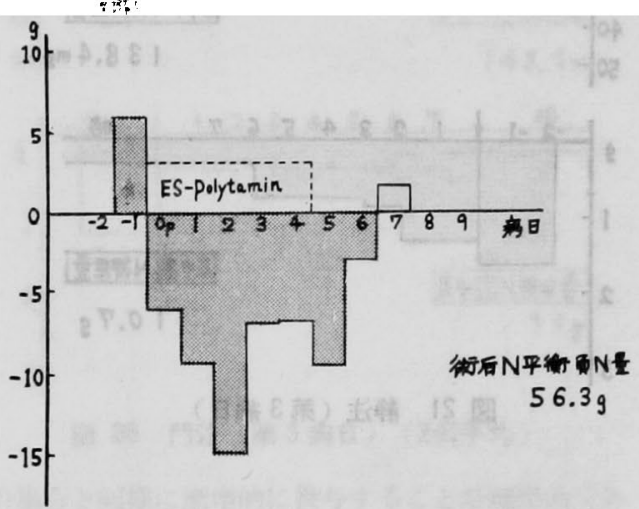

図 19 窒素平衡静注 (2例平均)

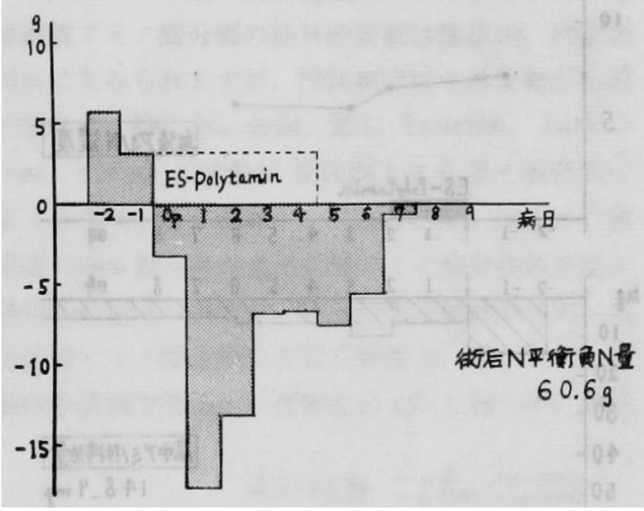

図 20 空素平得門注 (4例平均)

素平衡では静注と門注の間に 差異は認められませ ん。（図19，20）ES-Polytamin 200cc を投与した 場合に，その経時的変動をみますと，排泄アミノ空 素量は門注例では静注例に比べ $10.5 \mathrm{mg}$ ，約 $8 \%$ 多 いのでナが，排泄䌊空素量は窂ろ静注例で $1.3 \mathrm{~g}$, 約14\%を増量しておりまして, 門注例の方が尿中排 泄窒素剭の少いことが分ります。又門注例では静注 


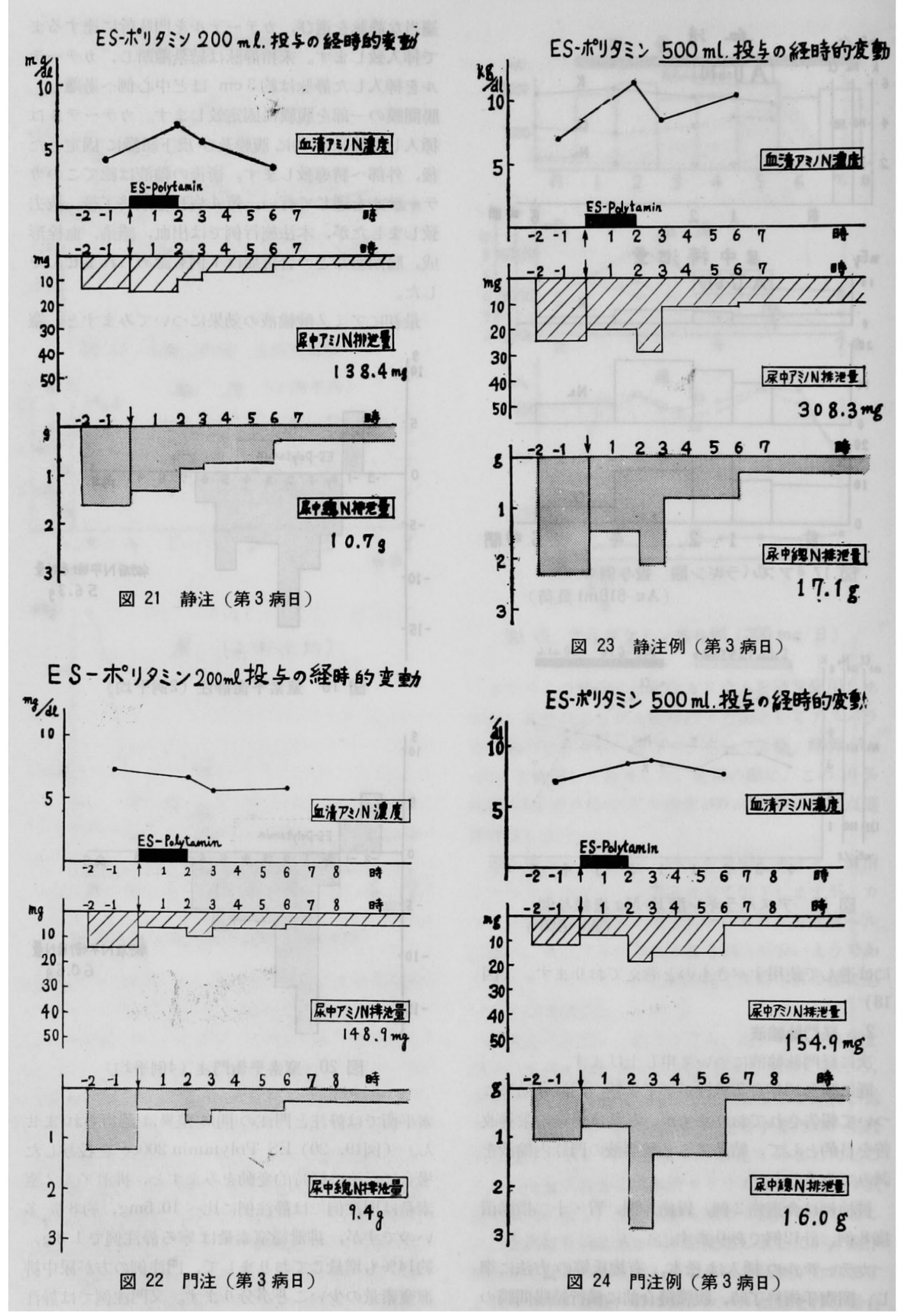


例に比べ尿中への窒素排洒のおくれる様相し見られ ます。血清丁ミノ空素浪度をみますと，静注例では 始めに増加し, 後で減少するといら変化を示します が，門注例では渐減するといら異つた梯相を示しま 寸。国21，22）

更にアミノ酸溶液を $500 \mathrm{cc}$ に増量して投与します と，門注例では静注例に比へ尿中排浛䌊窒素は 1.1 $\mathrm{g}$ 少く, 又アミノ窒素量も静注例の $1 / 2$ 量にへって おります。特に血清アミノ空素渡度の変動は門注例 に於て轱度でありまして，肝内に於てアミノ酸の排 泄が調節されるのではないかと考えられるふしもあ ります。（図23，24）

門注例で毎日 ES-Polytamin $200 \mathrm{cc}$ を投与した 場合を、第1病日と第 3 病日に経時的変動を䚁察し てみますと，第 1 病日では第 3 病日に比べ疗中排沚 窒素量とアミノ窒素量は夫々 3 倍， 3.4 倍とい5大 きさに達し，血清アミノ窒素浱度も第 1 病日には著 るしい変動がみられます。換言しますと，門注例で 6第 3 病日に比べ第 1 病日ではアミノ酸の利用事が 低下しております。（図25，26）やはり術後の異化 六進を防止することは門注でも不可能であります し，門注による術後のアミノ酸投与の揚合にも静注

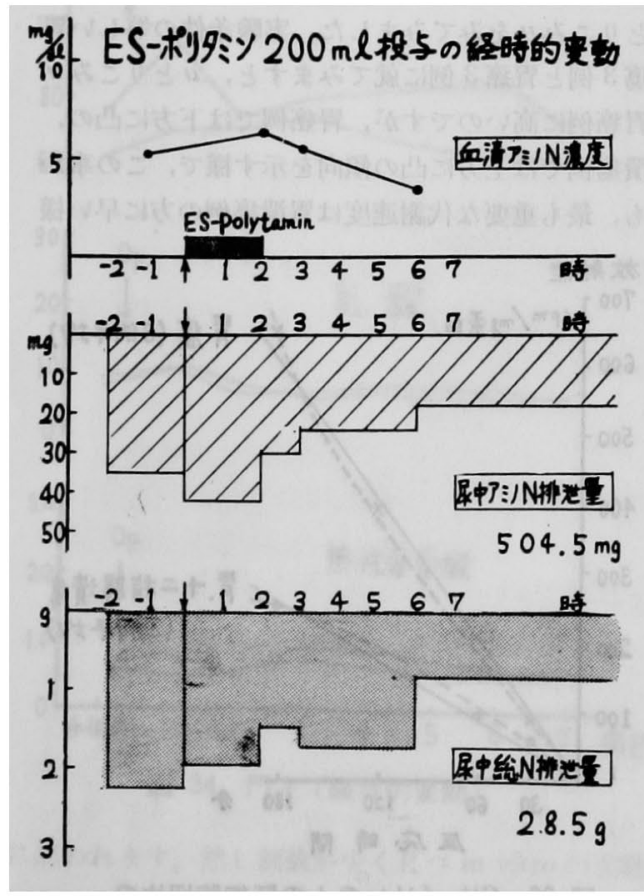

因 25 門注（第 1 病日）（2 例平均）

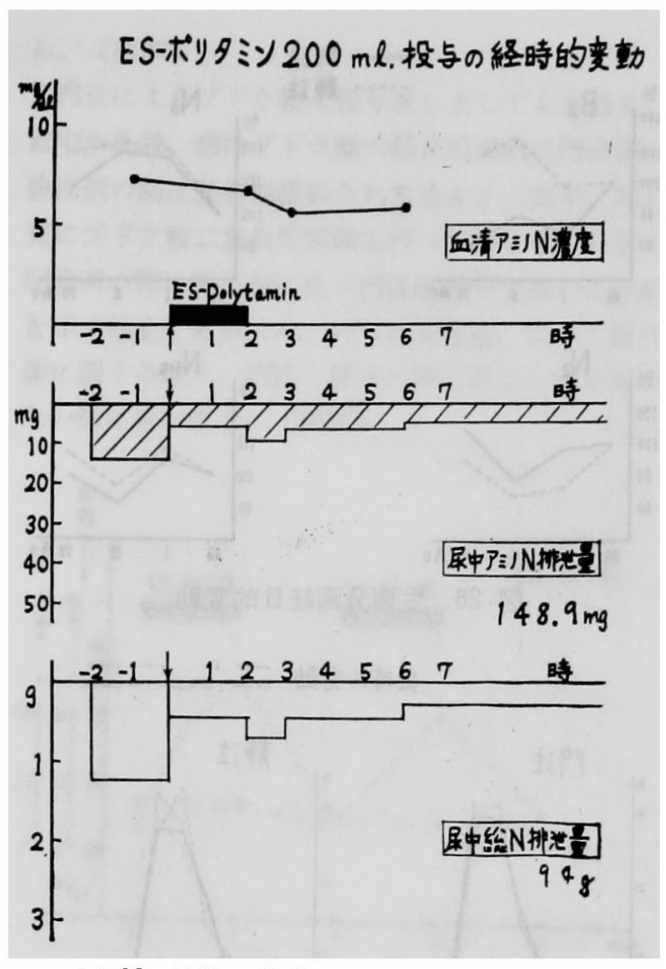

园 26 門注（第3病日）（2例平均）

の場合と同様に漸堌的に投与することが理想的であ ると思われます。

一方，アミノ酸の犋的変動についてみますと，血 清遊離アミノ酸分画の経日的変動は静注例, 門注例 何れにもみられますが, 門注例ではその変㲜が比㜞 的怪度で, 特に $\mathrm{N}_{3}$ 分画, 即ち Leucine, Isoleucine, Valine の変動は静注例よりも早く街前值に 復する傾向が見られます。（図27，28）又アミノ酸 溶液 200cc 投与後の血清遊離アミノ酸分画の変動を 経時的に追求しますと, 門注例では静注例に比べ血 清遊離アミノ酸分画の変動が軽度で，しかも $\mathrm{N}_{3}$ 分 画は静注例で著るしい变動を示すにも拘らず，門注

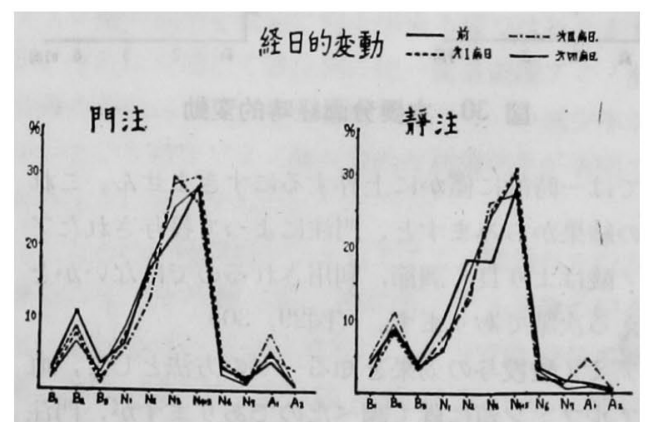

図 27 血清遊隻アミノ酸分画 

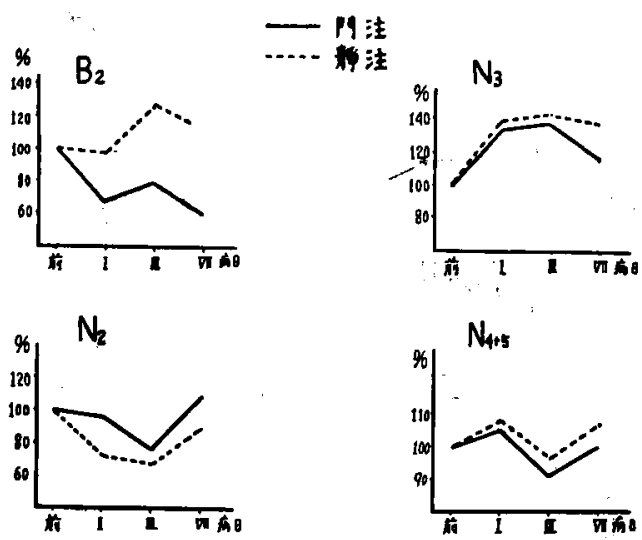

図 28 要分画経日的变行

$$
\text { 络時的变轩 - }
$$

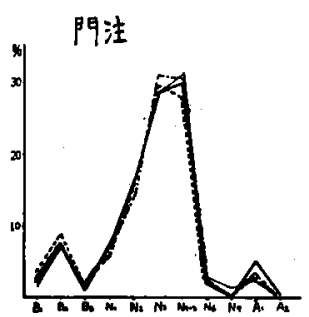

青注

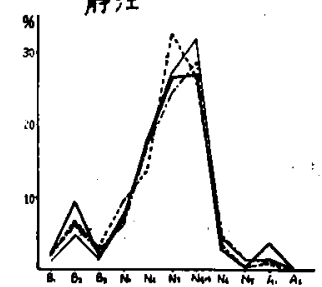

図 29 血清遊離アミノ酸分
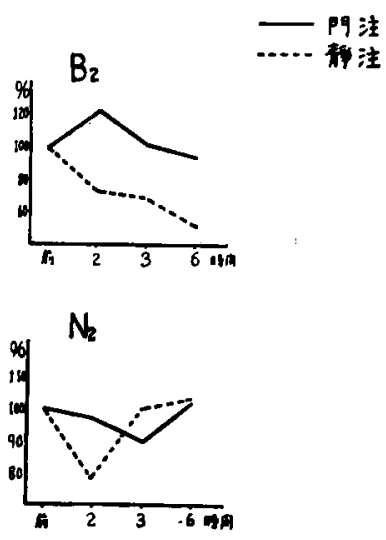

图 30，主要分画経時的变䃼

例では一時的に僅かに上昇するにすぎません。これ らの結果からみますと，門注によつて投与されたア ミノ酸はより良く調節, 利用されるのではないかと 名える次第であります。（汹29，30）

アミノ酸投与の効果を知る一つの方法として, “近 漿アルブミン值に就て調べたのでありますが，門注 例では血漿アルブミン值との両者は静注例に比べ減
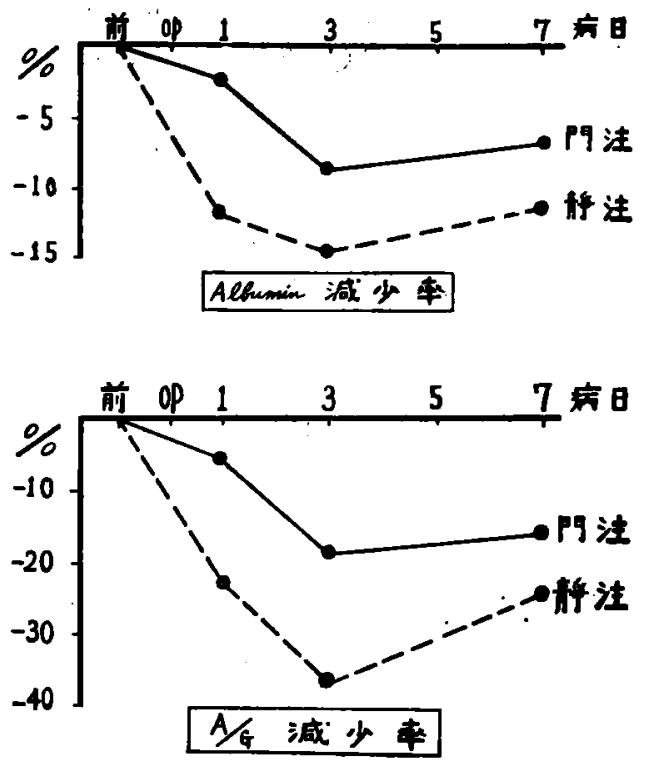

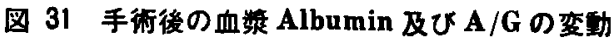
（静注 3 例, 門注 3 例)

少率の少いことが分ります。(図31)

勿論アミノ酸利用の第一段階として考えられるの は，肝内に於ける蛋白へのアミノ酸のいとりこみ 方"であります。私共は手術患者で開腹直後, 肔上 りとつた slice に就て $\mathrm{C}^{14}-$ Valine の全蛋白への "とりこみ!"をみてみました。実験条件の等しい胃 濽笏 3 例と胃癌 3 例に就てみますと，“とりこみ” は胃癌例に高いのですが，胃癌例では下方に凸の， 胃潰瘍例では上方に凸の傾向を示す様で，この事か らも，最も重要な代偣速度は胃渭绵例の方に早い憡

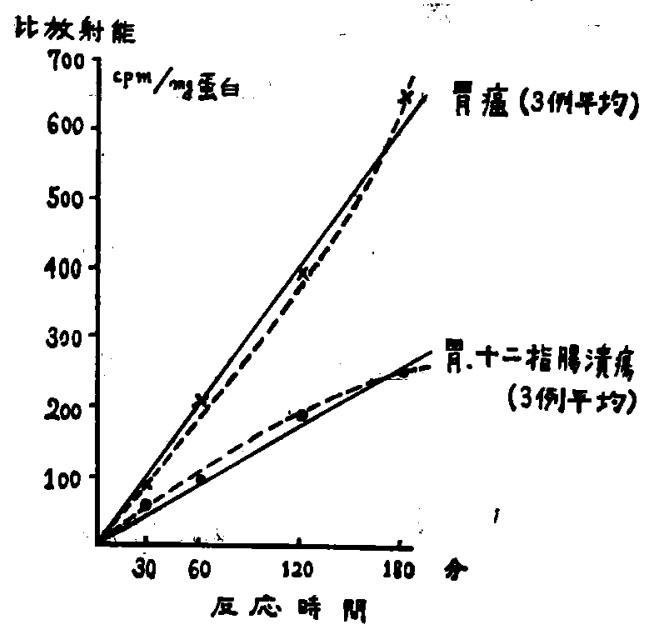

図 $32 \mathbf{C}^{14}$-バリンの人の肝細胞切片の 全蛋白へのとりこみ 

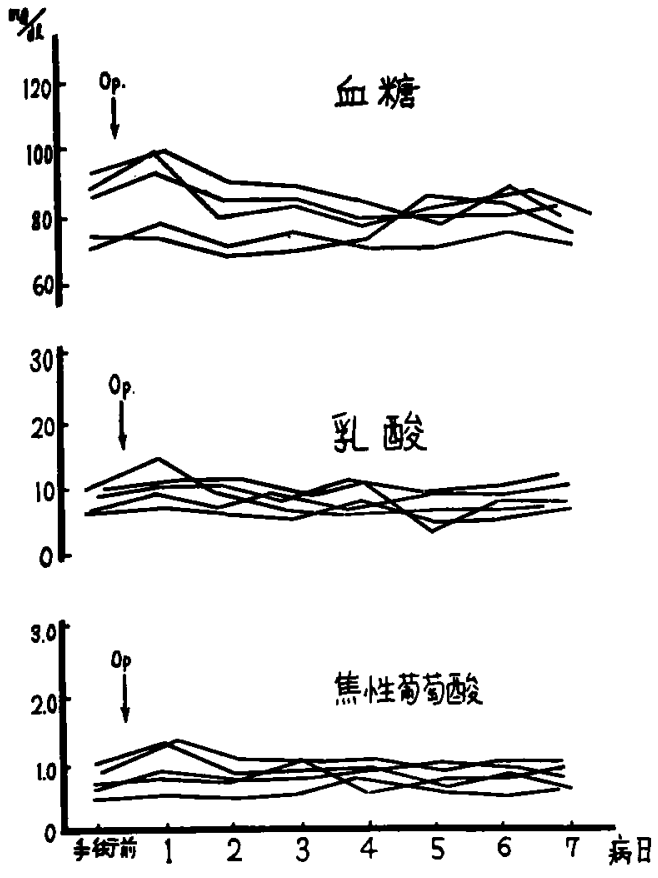

図 33 静注（経日的変動）
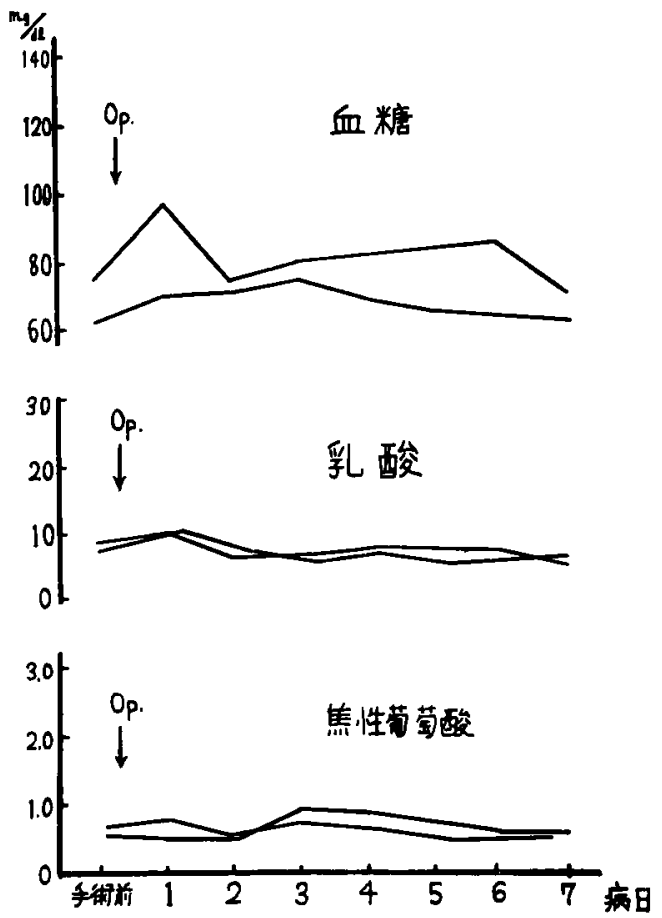

図 34 門注（経日的変動）

に照加れお。然し例数が少く且つ in vitroの騟

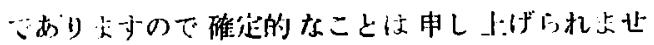

\section{h。（図32）}

門注によりブドウ糖を投与致しましても血䊀及び 血中の乳酸, 焦性ブドウ酸の経日的変動は門注例と 静注例の間に差異は認められません。（図33，34） 更にプドウ糖二重負荷試験を行ってみましても第 1 回負荷の際に静注例に比べ門注例がやや高い血糖值 を示す他全く差異はみとめられません。従つて糖代 謝に関する限り，門注と静注の間に著るしい差異は ない様に思います。（図35）
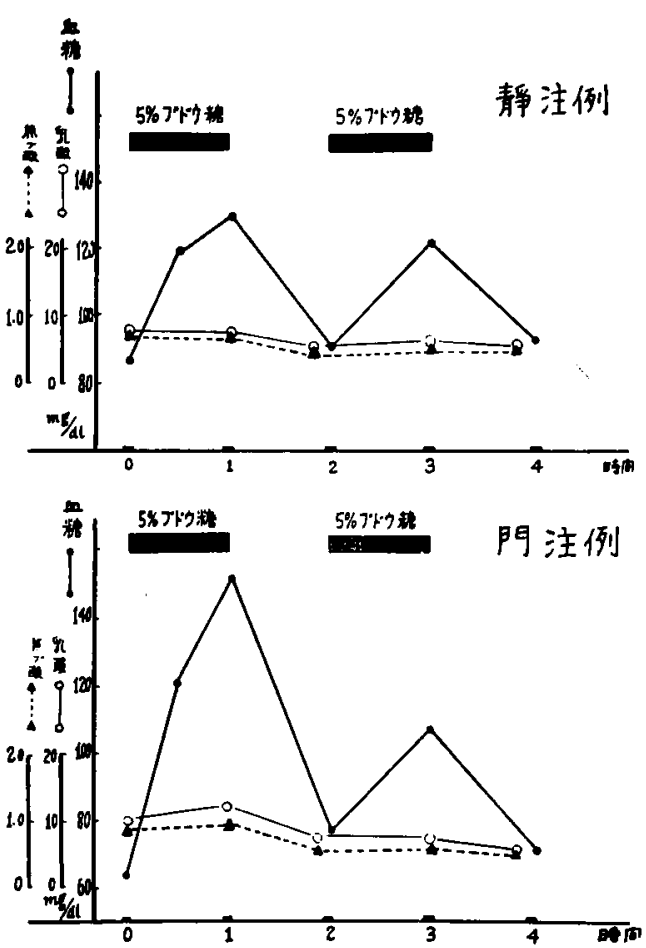

図 35 ブドウ糖二重員荷試験 $(0.5 \mathrm{~g} / \mathrm{kg} / \mathrm{hr})$

以上アミノ酸及びブドウ糖の経門脉輸液について 申し上げましたが，アミノ酸を門注することにより アミノ酸の利用を量的に向上出来る様ではあります が，それにも増して静注例に比べ血清遊離アミノ酸 分画の変動が少く, 且つ血浆アルブミンの減少率が 少いという様なアミノ酸の質的な利用刘果が著明で あるように感じました。

ともあれ，翰液の一つとしてアミノ酸投与を行う 場合には，その投与量，投与法，アミノ酸の配合 比, 或は患者の状態に留意し, 一方では適鼠の糖 質，脂倎を投与して蛋白節約作用を計り，更に Anabolic steroid を併用してアミノ酸の利用效果 
を高めるという多角的な配虑が望ましいるのと考え ます。

アミノ酸の投与量, 更にアミノ酸の配合比につき ましては今後に残された問題多く，私共もこの点に
関し，猶一層の追求を行いたいと思っている次第で あります。

御静聴有難うございました。 